\title{
UPAYA PENINGKATAN PRESTASI BELAJAR BAHASA INDONESIA MELALUI PEMANFAATAN MEDIA ALTERNATIF
}

\author{
Arum Ismawati \\ arumismawati@gmail.com \\ SDN Gedangan Kecamatan Sukodadi
}

\begin{abstract}
Abstrak
Permasalahan dalam penelitian ini adalah belum diketahui adanya pengaruh media alternatif terhadap peningkatan pemahaman mendeskripsikan unsur cerita pada siswa di kelas V SD Negeri Gedangan Kecamatan Sukodadi Kabupaten Lamongan. Untuk menjawab permasalahan tersebut maka peneliti mengajukan hipotesis yang berbunyi : jika pembelajaran dilakukan dengan menggunakan media alternatif, maka pemahaman mendeskripsikan unsur cerita pada siswa akan meningkat.

Penelitian ini menggunakan metode penelitian tindakan kelas yang terdiri dari beberapa siklus dengan setiap siklus terdapat perencanaan, tindakan, pengamatan, dan refleksi. Instrumen yang digunakan berupa Angket Siswa, Rencana Pembelajaran (RP), Lembar Kegiatan Siswa (LKS), dan penilaian kelas.

Penelitian ini dilakukan melalui dua siklus yaitu siklus I dan siklus II. Pada siklus I terdapat 13 siswa yang mengalami ketuntasan belajar perorangan dari 26 jumlah siswa (50\%) ini menunjukkan pada siklus ini belum mengalami ketuntasan klasikal. Pada siklus II semua mengalami ketuntasan belajar perorangan yaitu 26 siswa $(100 \%)$ ini menunjukkan pada siklus ini sudah mengalami ketuntasan klasikal.
\end{abstract}

Kata Kunci : Media Alternatif, Unsur Cerita

\section{PENDAHULUAN}

Pada masa lalu proses belajar mengajar selalu berfokus pada guru atau pengajaran dan materi kurang focus pada kompetensi pembelajaran siswa. Hasil analisis yang mendalam terhadap keadaan peserta didik dimasa sekarang dan yang akan datang memerlukan kualitas ketrampilan dan intelektualitas yang kompetitif, menunjukkan perlunya suatu metode, model dan strategi pembelajaran yang dapt membekali peserta didik untuk menghadapi tantangan kehidupan secara mandiri, cerdas, kritis, rasional dan kreatif.

Bertitik tolak dari latar belakang di atas maka penulis merumuskan permasalahannya sebagai berikut: (1) Bagaimana pengaruh pembelajaran dengan pemanfaatan media alternative terhadap peningkatan penguasaan mendeskripsikan unsure cerita pada siswa kelas V SD Negeri Gedangan Kecamatan Sukodadi Kabupaten Lamongan Tahun Pelajaran 2017/2018 ? (2) Bagaimana penggunaan media alternatif dalam pembelajaran Bahasa Indonesia siswa kelas V SD Negeri
Gedangan Kecamatan Sukodadi Kabupaten Lamongan Tahun Pelajaran 2017/2018?

Sesuai dengan permasalahan di atas, penelitian ini bertujuan untuk: (1) Mengetahui pengaruh pembelajaran dengan menggunakan media elektronik terhadap peningkatan mendeskripsikan unsur cerita pada siswa kelas V SD Negeri Gedangan Kecamatan Sukodadi Kabupaten Lamongan Tahun Pelajaran 2017/2018. (2) Mengetahui penggunaan media alternatif dalam pembelajaran Bahasa Indonesia siswa kelas V SD Negeri Gedangan Kecamatan Sukodadi Kabupaten Lamongan Tahun Pelajaran 2017/2018

Adapun maksud penulis mengadakan penelitian ini diharapkan berguna untuk: (1) Menambah pengetahuan dan wawasan penulis tentang peranan guru dalam meningkatkan pemahaman siswa belajar Bahasa Indonesia. (2) Sumbangan pemikiran bagi guru dalam mengajar dan meningkatkan 
pemahaman belajar Bahasa Indonesia terutama pada tingkat Sekolah Dasar.

Gerlach (1971: 8) mengemukakan bahwa jenis media pembelajaran yang biasa digunakan dalam kegiatan pendidikan dan pengajaran dapat digolongkan menjadi 8 (delapan) macam tipe, yaitu : (a) Benda sebenarnya, yang termasuk kategori ini meliputi: kejadian dan obyek atau benda tertentu yang menyerupai benda yang sebenarnya termasuk di dalamnya model, (b) Presentasi verbal, meliputi: media cetak, kata-kata yang diproyeksikan melalui slide, film strip, transparansi, catatan di papan tulis, majalah dinding, papan tempel dan sebagainya, (c) Presentasi grafis, meliputi: chart, grafik, peta, diagram, lukisan atau gambar yang sengaja dibuat untuk mengkomunikasikan suatu ide, ketrampilan atau sikap. Presentasi grafik mungkin dipertunjukkan melalui buku, slide, film strip, transparansi OHP dan sebagainya, (d) Potret kejadian (still picture), yakni potret dari bermacammacam obyek atau peristiwa yang mungkin dipresentasikan melalui buku, film strip, slide, majalah dinding dan sebagainya, (e) Film (motion picture), film atau video tape dari pemotretan atau syuting benda atau kejadian sebenarnya maupun film dari pemotretan gambar (film animasi), (f) Rekaman suara (audio recorder), dapat menggunakan bahasa verbal atau efek suara dan musik. Rekaman suara dapat dipakai secara klasikal, kelompok atau individual, (g) Program, meliputi: pengajaran berprogram, yakni sikwen dari informasi baik verbal, visual atau audio yang sengaja dibuat untuk merangsang adanya respon dari siswa. Dan ada juga yang menggunakan mesin (komputer atau mesin belajar), (h) Simulasi, yakni peniruan yang sengaja diadakan untuk mendekati atau menyerupai kejadian sebenarnya.

Hasil pembelajaran tidak hanya dapat dilihat pada penguasaan materi yang ujung pangkalnya adalah peningkatan nilai suatu mata pelajaran (prestasi belajar), tetapi juga pada peningkatan motivasi (minat), peningkatan pemahaman konsep, peningkatan ketrampilan baik ketarmpilan dalam bidang fisik, psikis, maupun sosial. (Nurhadi, 2004:26).

Perilaku belajar menurut Degeng (1991:5) dipengaruhi oleh tiga variabel yaitu:

1. Kondisi pembelajaran: mencakup semua variabel yang tidak dapat dimanipulasi, yakni : tujuan pembelajaran, isi pembelajaran dan karakteristik siswa.

2. Metode pembelajaran: mencakup semua cara-cara yang dipakai untuk mencapai tujuan pembelajaran dalam kondisi tertentu.

3. Hasil belajar: mencakup semua akibat yang muncul dari penggunaan metode pada kondisi tertentu. Variabel kondisi tidak dapat dimanipulasi, sedangkan variabel metode adalah variabel bebas dan parameter metode kedua ini berinteraksi untuk menghasilkan efek pada variabel hasil belajar sebagai variabel tergantung. (Degeng, 1991:5)

\section{METODE}

Penelitian ini menggunakan Penelitian Tindakan Kelas (PTK). Menurut Tim Pelatih Proyek PGSM, PTK (Classroom Action Research) adalah suatu bentuk kajian yang bersifat reflektif oleh pelaku tindakan yang dilakukan untuk meningkatkan kemantapan rasional dari tindakan mereka dalam melaksanakan tugas, memperdalam pemahaman terhadap tindakan-tindakan yang dilakukan itu, serta memperbaiki kondisi dimana praktek pembelajaran tersebut dilakukan. (Riduwan, 2004:3)

Sedangkan menurut Riduwan (2004:3) PTK adalah bentuk kajian yang bersifat sitematis reflektif oleh pelaku tindakan untuk memperbaiki kondisi pembelajaran yang dilakukan. 
Sesuai dengan jenis penelitian tindakan dari Kemmis dan Taggart yaitu berbentuk spiral dari siklus yang satu ke siklus yang berikutnya. Setiap siklus meliputi perencanaan (planning), tindakan (action), pengamatan (observation), dan refleksi (reflection). Langkah pada siklus berikutnya adalah perencanaan yang sudah direvisi, tindakan, pengamatan dan refleksi. Sebelum masuk pada siklus I dilakukan tindakan pendahuluan yang berupa identifikasi permasalahan. Instrumen yang digunakan dalam penelitian ini terdiri dari: (a) Wawancara / interview , (b) Rencana Pelaksanaan Pembelajaran ( RPP ), (c) Lembar Kegiatan Siswa, (d) Penilaian Kelas. Tujuan utama dari penelitian tindakan ini adalah untuk meningkatkan hasil

\section{SIKLUS I}

1. Tahap Perencanaan

Pada tahap ini peneliti mempersiapkan perangkat pembelajaran yang terdiri dari RP 1, LKS 1 dan alat-alat pengajaran yang mendukung.

\section{Tahap Kegiatan dan Pelaksanaan}

pembelajaran di kelas dimana guru secara penuh terlibat dalam penelitian mulai dari perencanaan, tindakan, pengamatan, dan refleksi.

Sebelum masuk pada siklus I dilakukan tindakan pendahuluan yang berupa identifikasi permasalahan. Siswa yang masuk pada kelas $\mathrm{V}$ adalah siswa sudah bisa meringkas sebuah informasi/pesan dengan menggunakan bahasanya sendiri.

Setelah dilakukan identifikasi masalah peneliti memasuki siklus I. Berikut ini adalah pemaparan per siklus dalam pembelajaran Bahasa Indonesia terutama materi menyampaikan informasidengan menggunakan media elektronik

Pada akhir proses belajar mengajar siswa diberi tes unjuk kerja dengan tujuan untuk mengetahui tingkat keberhasilan siswa dalam proses belajar mengajar yang telah dilakukan. Adapun data hasil penelitian pada siklus I adalah sebagai berikut:

Tabel 1.Rekapitulasi Nilai Tes Siklus I

\begin{tabular}{lll}
\hline No. & Uraian & Hasil Siklus I \\
1. & Nilai rata-rata tes & 63 \\
2. & Jumlah siswa yang tuntas belajar & 13 \\
3. & Persentase ketuntasan belajar & $50 \%$ \\
\hline
\end{tabular}

\section{Pengamatan}

Dari kedua tabel di atas dapat dijelaskan bahwa dengan menerapkan pemanfataan media IT diperoleh nilai ratarata belajar siswa 63 dan ketuntasan belajar mencapai $50 \%$ atau ada 13 siswa dari 26 siswa sudah tuntas belajar. Hasil tersebut menunjukkan bahwa pada siklus pertama secara klasikal siswa belum tuntas belajar, karena siswa yang memperoleh nilai $\geq 60$ hanya sebesar $60 \%$ lebih kecil dari persentase ketuntasan yang dikehendaki yaitu sebesar $\geq 85 \%$.

\section{Refleksi}

Pada tahap ini akan dikaji apa yang telah terlaksana dengan baik maupun yang masih kurang baik dalam proses belajar mengajar dengan media koran. Dari datadata yang telah diperoleh dapat diuraikan sebagai berikut:

Selama proses belajar mengajar
guru telah melaksanakan semua
pembelajaran dengan baik sesuai dengan
RP yang telah dibuat. Meskipun ada
beberapa aspek yang belum sempurna,
tetapi persentase pelaksanaannya untuk
masing-masing aspek cukup besar.

Selama proses belajar mengajar guru telah memua RP yang telah dibuat. Meskipun ada beberapa aspek yang belum sempurna, masing-masing aspek cukup besar. 


\section{SIKULS II}

1. Tahap Perencanaan.

Pada tahap ini peneliti mempersiapkan perangkat pembelajaran yang terdiri dari RP 2, LKS 2 dan alat-alat pengajaran yang mendukung. Karena pada siklus pertama masih belum tuntas terutama terdapat kekurangan yaitu siswa masih kesulitan menggunakan bahasa yang benar dan keruntutan informasi yang

\begin{tabular}{lll} 
& \multicolumn{2}{c}{ Table. 2 Rekapitulasi Nilai Tes Siklus II } \\
\hline No. & Uraian & Hasil Siklus II \\
1. & Nilai rata-rata tes & 78 \\
2. & Jumlah siswa yang tuntas belajar & 26 \\
3. & Persentase ketuntasan belajar & $100 \%$ \\
\hline
\end{tabular}

\section{Pengamatan}

Dari tabel IV.3. dan IV.4. di atas dapat dijelaskan bahwa dengan menerapkan metode pembelajaran dengan menggunakan media IT diperoleh nilai rata-rata belajar siswa 78 dan ketuntasan belajar mencapai $100 \%$ atau semua siswa sudah tuntas belajar. Hasil tersebut menunjukkan bahwa pada siklus kedua ini secara klasikal siswa sudah tuntas belajar, karena siswa yang memperoleh nilai $\geq 60$ sebesar $100 \%$ lebih tinggi dari persentase ketuntasan yang dikehendaki yaitu sebesar $85 \%$.

\section{Refleksi}

Pada tahap ini akan dikaji apa yang telah terlaksana dengan baik maupun yang masih kurang baik dalam proses belajar mengajar dengan menggunakan media elektronik. Dari data-data yang telah diperoleh dapat diuraikan sebagai berikut:

Selama proses belajar mengajar guru telah melaksanakan semua pembelajaran dengan baik sesuai dengan RP yang telah dibuat.

Berdasarkan data hasil pengamatan dan penilaian diketahui bahwa siswa sudah mengalami peningkatan pemahamannya tentang menyampaikan informasi. masih kurang, maka guru menggunakan LCD sebagai media dalam.

2. Tahap Kegiatan dan Pelaksanaan.

Pada akhir proses belajar mengajar siswa diberi tes unjuk kerja dengan tujuan untuk mengetahui tingkat keberhasilan siswa dalam proses belajar mengajar yang telah dilakukan. Adapun data hasil penelitian pada siklus II adalah sebagai berikut:

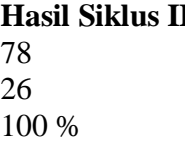

$100 \%$

Berdasarkan seluruh pembahasan serta analisis yang telah dilakukan dapat disimpulkan sebagai berikut: (1) Pembelajaran dengan menggunakan media alternative ( media IT ) dapat meningkatkan pemahaman mendeskripsikan unsur cerita pada siswa kelas V SD Negeri Gedangan Kecamatan Sukodadi Kabupaten Lamongan Tahun Pelajaran 2017/2018 yang ditandai dengan peningkatan ketuntasan belajar klasikal siswa dalam siklus I (50 \%) dan siklus II $(100 \%)$ dan peningkatan rata-rata siswa yaitu 65 pada siklus I menjadi 78 pada siklus II. (2) Pelaksanaan pembelajaran dengan menggunakan media alternatif ( media IT) telah berjalan dengan baik. Guru melakukan perbaikan pada siklus selanjutnya untuk mengurangi kelemahan maupun kesalahan dan menjauhkan hambatan yang dialami guru selama proses pembelajaran.

\section{DAFTAR PUSTAKA}

Arikunto, Suharsimi. 2002. Prosedur Penelitian Suatu Pendekatan Praktek. Jakarta: Rineksa Cipta.

Degeng $_{3}$, I.N.S. 1991. Karakteristik Belajar Mahasiswa Berbagai Perguruan Tinggi Di Indonesia. Jakarta PAU Universitas

\section{KESIMPULAN}


Reforma: Jurnal Pendidikan dan Pembelajaran

p-ISSN: 2503-1228; e-ISSN: 2621-4172

Terbuka Dirjen Pendidikan dan Kebudayaan.

Depdiknas, 2003, Kurikulum 2004 Standar Kompetensi Mata Pelajaran Bahasa Indonesia dan Sastra Indonesia untuk SD dan MI, Jakarta, Depdiknas.

Haryadi dan Zamzani, 1997, Peningkatan Ketrampilan Bahasa Indonesia, Proyek Pengembangan Guru SD, Yogyakarta.
Muclisoh, 1994, Pendidikan Bahasa Indonesia 5, Jakarta Depdiknas.

Pusat Pembinaan dan Pengembangan Bahasa Depdikbud, 1980, Pedoman Umum Ejaan Bahasa Indonesia Yang Disempurnakan, Jakarta : Balai Pustaka.

Suryadi, dkk. 1994, Pendidikan Bahasa Indonesia 5, Depdiknas : Jakarta. 